fournal of Medical Genetics (1970). 7, 356.

\title{
Adenosine Deaminase: Racial Distribution and Report of a New Phenotype*
}

\author{
J. C. DETTER, G. STAMATOYANNOPOULOS, E. R. GIBLETT, and
} A. G. MOTULSKY

From the Department of Medicine, University of Washington School of Medicine, Seattle, Washington 98105; and King County Central Blood Bank, Terry-at-Madison, Seattle, Washington 98104, U.S.A.

Genetic variation of the enzyme, adenosine deaminase (ADA), can be detected by starch gel electrophoresis of human red cell lysates and an appropriate staining procedure (Spencer, Hopkinson, and Harris, 1968). Three phenotypes (ADA 1, ADA 2-1, and ADA 2) appear to be determined by two structural alleles, $A D A^{1}$ and $A D A^{2}$. The frequency of the less common allele, $A D A^{2}$, was reported to be 0.03 and 0.05 in London Negroes and Caucasians, respectively. Its frequency among Asiatic Indians was 0.12 (Hopkinson, Cook, and Harris, 1969). A very rare ADA 3-1 phenotype, found in an English family, has also been described (Hopkinson et al., 1969).

\section{Material and Methods}

Blood was collected in ACD solution, the plasma removed, and the remaining packed cells washed three times with $0.9 \% \mathrm{NaCl}$ solution. Haemolysates for electrophoresis were prepared by diluting and mixing the packed cells with one volume of water and one-half volume of toluene. Stroma-free lysates, extracted after high-speed centrifugation, were subjected to vertical starch gel electrophoresis (Smithies, 1959) for 18 hours at $4^{\circ} \mathrm{C}$. and 6 volts per centimetre in sodium phosphate, pH 7, 0.1 M in the buffer trays and $0.005 \mathrm{M}$ in the gel. Enzymatic activity was localized as described by Spencer et al. (1968). Phenotypes were confirmed with the citrate buffer system described by Spencer et al. (1968). Phenotype frequencies were analysed by the $\chi^{2}$ distribution.

\section{Results and Discussion}

As shown in the Table, the gene frequencies in the Filipinos were identical to those of the Asiatic Indians. The phenotypes in Filipinos differed from the total European sample $(p<0.001)$, but the difference was less significant when the Filipino

\footnotetext{
Received 1 April 1970.

This work was supported in part by U.S. Public Health Service
}

TABLE

DISTRIBUTION OF ADENOSINE DEAMINASE TYPES IN VARIOUS POPULATIONS

\begin{tabular}{|c|c|c|c|c|c|}
\hline \multirow{2}{*}{ Ethnic Group } & \multirow{2}{*}{ Total } & \multicolumn{3}{|c|}{ Phenotypes } & \multirow{2}{*}{$\begin{array}{c}\text { ADA2 }^{2} \\
\text { Gene } \\
\text { Frequency }\end{array}$} \\
\hline & & 1 & $2-1$ & 2 & \\
\hline $\begin{array}{l}\text { European } \\
\text { Seattle } \\
\text { London* } \\
\text { Freiburgt } \\
\text { Greece }\end{array}$ & $\begin{array}{r}168 \\
1353 \\
302 \\
314\end{array}$ & $\begin{array}{r}152 \\
1223 \\
257 \\
260\end{array}$ & $\begin{array}{r}16 \\
127 \\
44 \\
52\end{array}$ & $\begin{array}{l}0 \\
3 \\
1 \\
2\end{array}$ & $\begin{array}{l}0.05 \\
0.05 \\
0.08 \\
0.09\end{array}$ \\
\hline $\begin{array}{l}\text { African } \\
\text { Seattle } \\
\text { London* } \\
\text { Other }\end{array}$ & $\begin{array}{l}186 \ddagger \\
300\end{array}$ & $\begin{array}{l}178 \\
283\end{array}$ & $\begin{array}{r}6 \\
17\end{array}$ & $\begin{array}{l}0 \\
0\end{array}$ & $\begin{array}{l}0.02 \\
0.03\end{array}$ \\
\hline $\begin{array}{l}\text { Mixed Oriental } \\
\text { Filipino } \\
\text { Asiatic Indian }\end{array}$ & $\begin{array}{l}118 \\
100 \\
460\end{array}$ & $\begin{array}{r}113 \\
80 \\
356\end{array}$ & $\begin{array}{r}5 \\
17 \\
100\end{array}$ & $\begin{array}{l}0 \\
3 \\
4\end{array}$ & $\begin{array}{l}0.02 \\
0.12 \\
0.12\end{array}$ \\
\hline
\end{tabular}

* Hopkinson et al. (1969).

+ Tariwerdian and Ritter (1969).

\# Includes two specimens with unusual phenotype (see text).

phenotypes were compared with the FreiburgGreece group $(0.05>p>0.02)$. Similar results were obtained from comparisons of Asiatic Indians and Europeans (Asiatic Indians vs Europeans, $\mathrm{p}<0.001$; Asiatic Indians vs Freiburg-Greek Europeans, $0.05>p>0.02$ ).

The difference in phenotype frequencies between the four groups of European origin is highly significant $(p<0.001)$. This difference is due to a higher frequency of $A D A^{2}$ in the Mid and Southern European sample (Seattle-London Caucasians vs Freiburg-Greek Caucasians, p < 0.001).

The phenotype frequencies of Seattle and London Negroes were nearly identical, but were significantly different from those in Freiburg-Greek Caucasians $(p<0.001)$, Seattle-London Caucasians $(0.01>p>$ $0.001)$, and the Asiatic Indians $(p<0.001)$. They were not different from the mixed Oriental sample (primarily Japanese).

These findings indicate a distinctive racial distribution of ADA phenotypes. The least poly- 


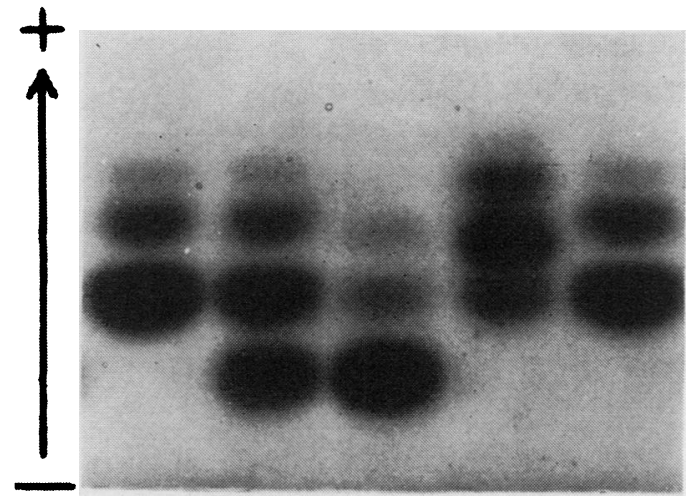

FIG. Starch gel electrophoresis of red cell adenosine deaminase. From left to right: Slots 1 and 5, ADA 1; slot 2, ADA 2-1; slot 3, ADA 2; slot 4, ADA 5-1. (Citrate buffer system-see text. All samples contained $20 \mathrm{mM}$ mercaptoethanol.)

morphism was observed in the Negroes and mixed Orientals. Northern Europeans had lower frequencies than Mid and Southern Europeans. The highest frequency was observed in two Asiatic groups (the Indians and the Filipinos).

In two Seattle Afro-Americans, the ADA electrophoretic pattern was different from the common penotypes (Fig.), from the published description (Hopkinson et al., 1969) of the low-activity ADA 3-1 pattern, and the phenotype reported by Dissing and Knudsen (1969). These two Seattle blood donors, with different surnames and presumably unrelated, were not available for further questioning or testing. Their ADA electrophoretic patterns, which were identical on several runs and unaffected by preincubation with mercaptoethanol (Spencer et al., 1968), appear to contain the set of products of the common $A D A^{1}$ gene and an additional set of products with slightly more rapid anodal migration. This phenotype has tentatively been designated '5-1',* though proof of its genetic origin from heterozygosity for $A D A^{1}$ and a rare $A D A^{5}$ gene remains to be established.

\section{Summary}

The adenosine deaminase (ADA) genetic polymorphism was examined in blood samples from five population groups. The distribution of the ADA phenotypes among these populations and the finding of a new phenotype are reported.

\section{REFERENCES}

Dissing, J., and Knudsen, J. B. (1969). A new red cell adenosine deaminase phenotype in man. Human Heredity, 19, 375-377.

Hopkinson, D. A., Cook, P. J. L., and Harris, H. (1969). Further data on the adenosine deaminase (ADA) polymorphism and a report of a new phenotype. Annals of Human Genetics, 32, 361-368. Smithies, O. (1959). An improved procedure for starch-gel electrophoresis: further variations in the serum proteins of normal individuals. Biochemical fournal, 71, 585-587.

Spencer, N., Hopkinson, D. A., and Harris, H. (1968). Adenosine deaminase polymorphism in man. Annals of Human Genetics, 32, 9-14.

Tariwerdian, G., and Ritter, H. (1969). Adenosine deaminase polymorphism (E.C.: 3.5.4.4): formal genetics and linkage relations. Humangenetik, 7, 176-178.

* Another phenotype has already been designated 4-1. (H. Harris (1969), personal communication). 